\title{
What's the Delay? Managing e and p Publication Dates
}

Gabrielle Wiersma

Collection Development and Assessment Librarian

University of Colorado Boulder Libraries

\begin{abstract}
This case study describes the challenges of acquiring eBooks on an approval plan due to publication delays between print and electronic formats. The purpose of this analysis was to determine the average delay between print and eBook publication dates so that appropriate hold periods could be built into the libraries' approval plan. Print publication dates were compared to eBook publication dates for approximately 30,000 eBooks to calculate the average delay between print and eBook availability. The data was further analyzed to calculate average delays for select publishers and subjects.
\end{abstract}

\section{Introduction}

For many libraries, eBooks are now the preferred format for a wide variety of subject areas. In some cases, it is still a challenge to streamline their selection and acquisition since eBooks and print books are rarely released simultaneously. Print is often available before an eBook equivalent and eBook availability is unpredictable. As a result, libraries face the difficult choice of waiting for an eBook or purchasing a title in multiple formats.

Some vendors have started to offer integrated approval plans for print and e-books to help libraries manage the acquisition of books in their preferred format. Both YBP Library Services and Ingram Information Services offer preferred format services within their approval plans, however, most these services are only effective for simultaneously published formats (Courtney 2002). If a library's preferred format is not available within a certain amount of time an alternate edition may be sent or the order may be cancelled.

Recognizing that a significant number of titles are not simultaneously published, Ingram developed a system called On Hold for Alternate Edition to help libraries manage the delay between publication dates of various formats. On Hold for Alternate Edition allows libraries to delay the purchase of a title until it is available in a preferred format. While this service offers flexibility in terms of how long to wait for an alternate edition, it can be difficult for libraries to establish accurate On Hold periods. In addition, there are no guarantees that an alternate edition will ever be published and libraries risk that a print title will go out of stock while waiting for an eBook. 


\section{Literature Review}

The literature provides evidence that libraries have struggled to acquire materials in a preferred format for as long as there have been multiple formats for libraries to select (Strauch and Miller 1993, Worley, 2000, Levine-Clark 2007, Buckley and Tritt 2011, Hodges, Preston, and Hamilton 2010). Preferred format services gained popularity in the 1980's when libraries realized there was significant cost savings in purchasing paperbacks instead of cloth editions (Worley 2000, Courtney 2002). Approval vendors started offering paper-preferred approval plans and preferred edition services for UK and US editions in the early 90's, however, publication delays between cloth and paperback and U.S. and U.K. editions prevented approval vendors from supplying a preferred edition unless it was simultaneously published in both formats (ibid.). Courtney $(2002,203)$ describes the ability to supply alternate editions on approval as, "a condition of doing business" for any approval vendor and the addition of eBooks as a preferred format is no exception.

Acquiring eBooks as a preferred format is challenging because eBooks tend to be released after print editions and there is no guarantee that an eBook will ever be published. Approximately $20-25 \%$ of the books treated by approval vendors are available in both print and electronic formats and an even smaller percentage of eBooks are available simultaneously with print (Levine-Clark 2010). Consequently, many libraries purchase the format is available first, even if it is not their preferred format (Miraglia, Dean, Fennessy, and Jennings 1995, Anson and Connell 2009, Hodges, Preston, and Hamilton 2010, Duke University Press 2011).

Many libraries have identified the publication delay between print and eBooks as an obstacle to collecting eBooks (Levine-Clark 2007 and 2010, Anson and Connell 2009, Duke University Press 2011, Buckley and Tritt 2011). Results from a survey of 123 ARL member libraries in March 2009 identifies the "lag time between print and electronic publication (with electronic the lagging format)" as a problem for libraries who would prefer to purchase eBooks instead of print $(2009,11)$. The survey also remarks that "eBook purchases would increase if the e-format was available at the same time as the print version." (Anson and Connell 2009, 15). Hodges, Preston, and Hamilton $(2010,198)$ summarize the challenges facing libraries, "Few libraries want to buy the same content twice. So should the library defer buying the title while only the hardcover is available in the hope that the e-book will be released soon? Or buy the hardcover and forgo eventual purchase of the e-book, a format that many patrons now prefer?"

Respondents to the Duke University Press "Survey of Library E-Book Acquisitions" also commented that a main issue for librarians "is that it is not always clear which titles will be available as e" (Duke University Press 2011,12 ). The availability of eBooks is still unpredictable and varies by publisher. The 
2009 ARL SPEC Kit for E-book Collections describes the timing of eBook publication as an industry level challenge because publishers are still making decisions about publication sequences based on print sales (Anson and Connell 2009). Many publishers are still concerned about protecting print sales and are opting to delay the release of an eBook until cloth and sometimes even paperback sales have peaked (Hodges, Preston, and Hamilton 2010).

Unpredictable publishing sequences also make it difficult for approval vendors to supply preferred formats to libraries. Most approval vendors can only supply an alternate format if both editions are published simultaneously (Courtney 2002, Levine-Clark 2007). Print is often profiled and sent on approval before an eBook is available and most profiles have mechanisms to prevent duplication of format. Levine-Clark (2007, p.18) reasons "though we do not need publishers to make all titles available in eBook form, we do need to understand the patterns they are using in order to write eBook coverage into our approval plan". Libraries and approval vendors need to understand the order that formats will be published as well as an approximate amount of time between each release in order to acquire a preferred format.

\title{
FIGURE 1. Unpredictable Publishing Sequences
}

\author{
Cloth $\rightarrow$ Paperback $\rightarrow$ eBook \\ Cloth $\rightarrow$ eBook $\rightarrow$ Paperback \\ eBook $\rightarrow$ Cloth $\rightarrow$ Paperback \\ Cloth $\rightarrow$ Paperback (No eBook is ever published)
}

Embargo periods can also prevent approval vendors from providing eBooks as a preferred format. Unlike lag times caused by the normal production process, embargo periods are intentional delays between the release of formats or editions that publishers use to control the sales of their content. The goal of embargo periods is to maximize profit for one format (e.g. cloth) before releasing additional formats (e.g. paperback or eBook). Similarly, publishers who have developed their own eBook platforms can use embargo periods to maximize direct their eBook sales. Publishers entice libraries to purchase eBooks directly from them by offering simultaneous publication on their own platforms and imposing embargo periods when eBook aggregators are not allowed to distribute their content (Levine-Clark 2007, Hodges, Preston, and Hamilton 2010). This is problematic for approval book vendors like YBP and Ingram because they work with eBook aggregators like ebrary, EBL, and My iLibrary to supply eBooks on approval.

Defining simultaneous publication is another industry level challenge. In 1997, Blackwell stated that "a book is published simultaneously when both the cloth and paper editions, or both the US and UK editions, 
appear within a particular window of time" (Wagner, 1997, 51). Without industry consensus regarding simultaneous publication, each approval vendor has developed different waiting periods for alternate editions. Blackwell's Paper Preferred service only supplied paper editions instead of cloth if the paper edition was available within 60 days (Worley 2000). Similarly, YBP will wait no longer than eight weeks for an alternate edition and Ingram will wait a maximum of 180 days. If a library's preferred format is not available within that "particular window of time" an alternate edition may be sent or the order may be cancelled. Consequently, if an eBook is published more than 60 days after the cloth most approval vendors cannot supply it on approval (Courtney 2002).

\section{Purpose and Methodology}

The University of Colorado Boulder (UCB) Libraries worked with Ingram to build an integrated approval plan for print and eBooks. The approval profile includes more than sixty subject-based sub-profiles each with different instructions for eBooks. The Libraries opted to use Ingram's On Hold for Alternate Edition service but we were uncertain about how long to delay the purchase of a print edition while waiting for an eBook to become available.

Since the scholarly importance of monographic materials varies by discipline, the Libraries chose different On Hold periods for each subject. UCB's science librarians wanted to maximize the number of eBooks received on approval so they chose the longest On Hold period of 180 days. UCB's social science and humanities librarians were also interested in selecting eBooks on approval, however, monographs are more important to research and teaching in these subject areas so our librarians did not feel comfortable delaying the purchase of a print book for more than 60 days.

While these On Hold periods helped us get our profiles up and running, we wanted to establish On Hold periods that reflected actual publication delays between print and eBooks. The purpose of this analysis was to determine the average delay between print and eBook publication dates so that appropriate hold periods could be built into the libraries' approval plan profile. Ingram was able to provide a list of all of the eBooks that were treated on their approval plans in 2008-2011. eBooks without print equivalents were removed from the sample. Print publication dates were compared to eBook publication dates for approximately 30,000 eBooks to calculate the average delay between print and eBook availability. The data was further analyzed to calculate average delays for select publishers and subjects.

While most approval plans aim to supply newly published works approximately $30 \%$ of the eBooks treated on approval in 2008-11 were published in print more than a year before the eBook was published. Comparing the original print publication date to the eBook publication date for these backlist titles could 
result in a longer overall delay, so the data for newly published works were separated from reprint and subsequent editions in order to estimate the publication delays.

\section{TABLE 5. Newly Published Works}

\begin{tabular}{|l|c|c|c|c|}
\hline & $\mathbf{2 0 0 8}$ & $\mathbf{2 0 0 9}$ & $\mathbf{2 0 1 0}$ & $\mathbf{2 0 1 1}$ \\
\hline $\begin{array}{l}\text { Number of eBooks Classified as } \\
\text { Newly Published Works }\end{array}$ & $4,636(67 \%)$ & $7,184(66 \%)$ & $13,782(68 \%)$ & $12,782(70 \%)$ \\
\hline
\end{tabular}

\section{Results}

Overall, the average delay between print and eBooks has decreased over the past four years. While it used to be necessary to wait more than 60-180 days for an eBook, in 2010 eBooks were available within eight days of their print equivalents and in 2011 eBooks were often available before print. While this data suggests a trend towards simultaneous publication, further analysis shows that the average delay for specific subjects and individual publishers can vary widely.

TABLE 1. Overall Average Delay and Sample Size

\begin{tabular}{|l|c|c|c|c|}
\hline & $\mathbf{2 0 0 8}$ & $\mathbf{2 0 0 9}$ & $\mathbf{2 0 1 0}$ & $\mathbf{2 0 1 1}$ \\
\hline Number of eBooks Treated on Approval & 5,076 & 7,952 & 15,103 & 13,715 \\
\hline $\begin{array}{l}\text { Average Number of Days Print is } \\
\text { Available Before eBook for All Titles }\end{array}$ & 177 & 79 & 9 & -1 \\
\hline $\begin{array}{l}\text { Average Number of Days Print is } \\
\text { Available Before eBook for Newly } \\
\text { Published Works }\end{array}$ & 176 & 68 & 11 & -1 \\
\hline
\end{tabular}

\subsection{Subject Trends}

Subject trends were identified by grouping the sample eBooks according to LC classification. General subjects originated from the Library of Congress Classification Outline (http://www.loc.gov/catdir/cpso/lcco) and subject assignments in UCB Libraries' approval profile. Table 2 lists 29 subjects and the average number of days between the publication of print and eBook editions in 2010.

TABLE 2. Subject Trends

\begin{tabular}{|l|c|}
\hline Print Before eBook & $\begin{array}{l}\text { Avg. \# Days } \\
\text { Between Editions }\end{array}$ \\
\hline Agriculture & 21 \\
\hline Art and Architecture & 45 \\
\hline Astronomy & 33 \\
\hline Biology & 16 \\
\hline
\end{tabular}

\begin{tabular}{|l|c|}
\hline eBook Before Print & $\begin{array}{l}\text { Avg. \# Days } \\
\text { Between Editions }\end{array}$ \\
\hline Anthropology & 4 \\
\hline Education & 8 \\
\hline Environmental Studies & 5 \\
\hline Library Science & 11 \\
\hline
\end{tabular}




\begin{tabular}{|l|c|}
\hline Business & 15 \\
\hline Classics & 63 \\
\hline Chemistry & 30 \\
\hline Computer Science & 26 \\
\hline Economics & 2 \\
\hline Engineering & 42 \\
\hline Geology & 33 \\
\hline History & 7 \\
\hline Law & 36 \\
\hline Music & 3 \\
\hline Math & 50 \\
\hline Military Science & 6 \\
\hline Medical Science & 14 \\
\hline Physics & 10 \\
\hline Religious Studies & 63 \\
\hline Science/Technology & 14 \\
\hline
\end{tabular}

\begin{tabular}{|l|c|}
\hline Literature & 31 \\
\hline Philosophy & 23 \\
\hline Political Science & 3 \\
\hline Psychology & 19 \\
\hline Sociology & 5 \\
\hline & \\
\hline & \\
\hline & \\
\hline & \\
\hline & \\
\hline & \\
\hline & \\
\hline & \\
\hline & \\
\hline & \\
\hline
\end{tabular}

On average, eBooks were more likely to be published before print in the social sciences and humanities instead of the sciences as would be generally expected. This data also indicated that the Libraries needed to adjust the waiting periods for On Hold for Alternate Edition in the approval plan. UCB Libraries' science profiles were initially set up to wait 180 days for an alternate edition but this data revealed that a 60 day On Hold period would be adequate. Similarly, a 45 day On Hold period would be sufficient for most subjects in the social sciences and humanities. After reviewing the data, UCB Libraries reduced the waiting period for science profiles from 180 days to 60 days and 30-45 days for social sciences profiles.

\subsection{Publisher Trends}

The 2010 sample data included approximately 11,000 titles from more than 200 trade publishers. Table 3 lists select trade publishers who are likely to produce eBooks and the average number of days between the publication of cloth and eBook editions in 2010. Table 3 illustrates that there are still many more publishers who publish print books before eBooks.

TABLE 3. Publisher Trends-Trade

\begin{tabular}{|l|c|}
\hline Print Before eBook & $\begin{array}{l}\text { Avg. \# Days } \\
\text { Between Editions }\end{array}$ \\
\hline ABC-CLIO & 7 \\
\hline Addison-Wesley & 245 \\
\hline Apress & 369 \\
\hline Ashgate & 24 \\
\hline Berghahn Books & 5 \\
\hline Brill & 290 \\
\hline CRC Press & 2 \\
\hline Edward Elgar & 72 \\
\hline Elsevier & 1 \\
\hline
\end{tabular}

\begin{tabular}{|l|c|}
\hline eBook Before Print & $\begin{array}{l}\text { Avg. \# Days } \\
\text { Between } \\
\text { Editions }\end{array}$ \\
\hline Continuum & 37 \\
\hline Earthscan & 8 \\
\hline Emerald & 28 \\
\hline IOS Press & 99 \\
\hline Palgrave Macmillan & 7 \\
\hline Sage & 83 \\
\hline Taylor and Francis & 48 \\
\hline & \\
\hline & \\
\hline
\end{tabular}




\begin{tabular}{|l|c|}
\hline Humana Press & 142 \\
\hline IGI Global & 1 \\
\hline McFarland & 40 \\
\hline McGraw Hill & 1 \\
\hline Rowman \& Littlefield & 18 \\
\hline Scarecrow Press & 77 \\
\hline Springer & 96 \\
\hline Wiley & 24 \\
\hline World Scientific & 13 \\
\hline
\end{tabular}

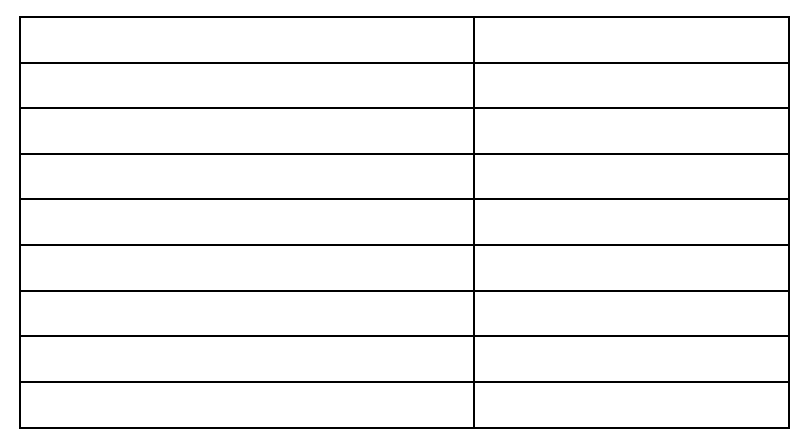

While it is possible for libraries to wait for books to be published in their preferred format it is very difficult for a library to receive eBooks on approval from publishers with an average delay of more than 180 days. Approval services like On Hold for Alternate Edition have a maximum waiting period of 180 days so if an eBook is not available within 180 days of print the approval vendor will routinely send the print. Ingram estimates that approximately $30 \%$ of titles placed On Hold for Alternate Edition do not come as eBooks because an eBook is not published within the On Hold period or is not published at all.

In addition, if libraries wait longer than 180 days to purchase print they risk that a title could go out of stock while waiting for an eBook. After six months many publishers have finished their first print run and monographic vendors have sold through their print inventory. Waiting for a second print run can cause additional delays and the library might have to purchase these titles from another monographic vendor or out of print service if their approval vendor is unable to supply them. Consequently, longer On Hold periods may be more effective for larger publishers who are likely to create larger print runs or for publishers who offer print on demand services but could be risky for smaller publishers.

The sample data also included more than 3,000 titles published by University Presses. Table 4 lists University Presses who are likely to produce eBooks and the average number of days between the publication of cloth and eBook editions. The majority of University Presses offer eBooks within 60 days of a cloth edition and many Presses are publishing eBooks before print.

TABLE 4. Publisher Trends-University Presses

\begin{tabular}{|l|c|}
\hline Print Before eBook & $\begin{array}{l}\text { Avg. \# Days } \\
\text { Between Editions }\end{array}$ \\
\hline Cambridge University Press & 12 \\
\hline Columbia University Press & 11 \\
\hline Fordham University Press & 18 \\
\hline MIT Press & 4 \\
\hline
\end{tabular}

\begin{tabular}{|l|c|}
\hline eBook Before Print & $\begin{array}{l}\text { Avg. \# Days } \\
\text { Between Editions }\end{array}$ \\
\hline $\begin{array}{l}\text { Hong Kong University } \\
\text { Press }\end{array}$ & 10 \\
\hline Indiana University Press & 12 \\
\hline $\begin{array}{l}\text { McGill-Queen's } \\
\text { University Press }\end{array}$ & 29 \\
\hline $\begin{array}{l}\text { Oxford Scholarship } \\
\text { Online }\end{array}$ & 7 \\
\hline
\end{tabular}




\begin{tabular}{|l|c|}
\hline Oxford University Press & 4 \\
\hline Princeton University Press & 31 \\
\hline University of California Press & 8 \\
\hline University of Chicago Press & 71 \\
\hline $\begin{array}{l}\text { University Press of New } \\
\text { England }\end{array}$ & 65 \\
\hline Yale University Press & 53 \\
\hline
\end{tabular}

\begin{tabular}{|l|c|}
\hline Rutgers University Press & 5 \\
\hline Temple University Press & 3 \\
\hline UBC Press & 67 \\
\hline $\begin{array}{l}\text { University of Wisconsin } \\
\text { Press }\end{array}$ & 4 \\
\hline $\begin{array}{l}\text { University Press of } \\
\text { Mississippi }\end{array}$ & 7 \\
\hline & \\
\hline
\end{tabular}

\section{Discussion}

Managing publication delays with an integrated approval plan is simply one option for libraries and this data may be useful for other libraries as well. In order to acquire eBooks as a preferred format, libraries and approval vendors need more information about eBook availability. Libraries and approval vendors need to know which publishers are likely to produce eBooks as well as the average publication delay between eBooks and equivalent formats. This information can be built into integrated approval plan profiles or used to inform other collection development decisions.

Most approval plans are driven by profiles in an automated computer system. Like any tool, they only work as well as they are programmed and their efficacy is affected by the quality of metadata that populates the system. Incomplete or inaccurate metadata disrupts the system and creates errors. For example, if the estimated publication dates that are included in prepublication information are too far apart from the actual publication dates then the system may not be able to accommodate instructions for waiting periods like On Hold for Alternate Editions. The metadata that is produced and shared with approval vendors needs to be evaluated and updated in order for automated approval systems to function effectively. Currently, approval vendors spend a lot of time and effort making sure that works in multiple formats are described in the same way so that the title matches a library's profile the same way regardless of format. However, forthcoming improvements to ONIX metadata standards could improve the quality of data that is shared and received.

Libraries also need to balance our goals of building a collection in a preferred format with our ability to provide materials to our users in a timely manner (Sievers-Hill 2010). While imposing a 90-180 day delay period would maximize the number of eBooks a library could acquire it is important for libraries to consider how those delays affect users. Users might not understand why the library does not own a recently published book and they might be unwilling to wait for the library to get a copy. Collection Development started monitoring purchase suggestions and interlibrary loan requests for books to determine if users were requesting books that were On Hold for Alternate Edition. In the event a title is 
requested Collection Development can order it immediately in print instead of waiting for an alternate edition.

From a publisher's perspective, simultaneous publication of print and eBooks needs to be profitable and demand for eBooks needs to precede supply. Data from approval vendors like YBP shows that eBook sales are growing as print sales decline and this trend will probably continue if libraries are able to select eBooks as a preferred format (Zeoli 2012). There is also evidence that publishers who produce eBooks and print simultaneously are more likely to gain sales from libraries. For example, YBP has presented data for a major social sciences and humanities publisher who sold more eBooks in the first quarter of 2012 than all of 2011 by increasing simultaneously availability of print eBooks (ibid.). This change was accompanied by a dramatic $61 \%$ increase for eBooks sales by the end of the first quarter alone (ibid). This is just one example of how simultaneous publication of print and eBooks could be mutually beneficial for libraries, approval vendors, and publishers.

\section{Conclusion}

The purpose of this analysis was to determine the average delays between print and eBook publication and apply that data to an approval plan. Using the average publication delays to establish the On Hold for Alternate Edition periods helped UCB Libraries build an approval plan that reflects publishing trends and allows the library to maximize the number of eBooks received on approval.

The data highlights some of the publishers and subject areas where print lags behind eBook availability but it also indicates that a growing number of publishers are offering simultaneous publication or even releasing an eBook before a cloth edition. Based on this data analysis, it may not be necessary to set up On Hold for Alternate Editions for all publishers but adding a 30-60 day delay period would significantly increase the number of eBooks a library could acquire on approval. Understanding the publishing patterns for publishers or subject areas could also help libraries without approval plans determine how long to wait for an eBook before purchasing print.

Publication delays can make it challenging for libraries to acquire eBooks on approval but this data analysis presents evidence that publishers are moving towards simultaneous publication. Simultaneous publication of cloth and eBooks would allow libraries to acquire more eBooks on approval, but in the meantime, many approval vendors have developed innovative services to help libraries acquire materials in a preferred format. Integrated approval plans can be effective tools for managing print and eBook selection and acquisition because libraries can designate eBooks as a preferred format and prevent duplication. In addition, services like On Hold for Alternate Edition can help libraries manage 
unpredictable publishing delays between print and eBooks. It is clear that there is still a need for cooperation between publishers, libraries, and book and serials vendors to develop mutually beneficial solutions for eBooks and other preferred formats.

\section{References}

Anson, Catherine, and Ruth R. Connell. (2009). E-book collections. SPEC kit. Vol. 313. Washington, DC: Association of Research Libraries.

Buckley, Matthew, and Deborah Tritt. (2011). Ebook approval plans. Computers in Libraries 31 (3) (04): $15-8$.

Courtney, Dana. (2002). The cloth-paper conundrum: The economics of simultaneous publication. Journal of Scholarly Publishing 33 (4) (07): 202.

Duke University Press (2011). Survey of library e-book acquisitions. Duke University Press. Available at: http://www.dukeupress.edu/Assets/Downloads/SurveyofLibraryEbookAcqusitions_DukeUP.pdf (Accessed August 1, 2011).

Hodges, Dracine, Cyndi Preston, and Marsha J. Hamilton. (2010). Resolving the challenge of E-books. Collection Management 35 (3) (Jul): 196-200.

Levine-Clark, Michael. (2010). Developing a multiformat demand-driven acquisition model. Collection Management 35 (3) (Jul): 201-7.

Levine-Clark, Michael. (2007). Electronic books and the approval plan: Can they work together? Against the Grain 19 (2) (04): 18-22.

Miraglia, K. J., B. C. Dean, E. T. Fennessy, and A. Jennings. (1995). A survey of ATG subscribers: Do you buy paperbacks rather than clothbacks when both are available? Against the Grain 7 (3) (Jun): 22-3.

Sievers-Hill, Arelene Morrow. (2010). Building library collections in the 21st century -- how goes the book approval plan in the days of the eBook? Against the Grain 22 (6) (Dec2010): 73-73.

Strauch, K., and H. Miller. (1993). Cloth over paper or paper over cloth - up to you. Against the Grain 5 (3) (Jun):9-12. 
Worley, Glen. (2000). Squeezing the most out of the approval plan budget: The University of Texas at Austin and Blackwell's book services preferred edition and paper preferred options. Against the Grain 12 (3): 16-26.

Zeoli, Michael. (2012). Consortia on Trial: ebook Trials and Tribulations. Presentation at the Electronic Resources and Libraries Conference, April 4, 2012, Austin, TX. 